\title{
Stand structure and populations of yew (Taxus baccata L.) in the Cisy Rokickie and Bogdanieckie Cisy reserves
}

\author{
Dorota Dobrowolska $^{1 凶}$, Grażyna Olszowska ${ }^{1}$, Marzena Niemczyk ${ }^{2}$ \\ Forest Research Institute, ${ }^{1}$ Department of Forest Ecology, \\ ${ }^{2}$ Department of Silviculture and Genetics, Sękocin Stary, ul. Braci Leśnej 3, 05-090 Raszyn, Poland. \\ Tel. +48 22 7150415, e-mail: D.Dobrowolska@ibles.waw.pl
}

\begin{abstract}
Yew Taxus baccata L. is an endangered tree species in parts of Europe. In Poland small populations grow in forest reserves. The study was conducted in two reserves established particularly for the protection of yew populations located in the regon of Pomerania. The aim of the study was to know the number, vitality and growth conditions of natural yew regeneration and to identify threats to the regeneration of the species. The stand structure and regeneration of yew was described in 30 circular plots. The main tree species in stand canopy was Scots pine, however in 'Bogdanieckie Cisy' beech also made up an important element of the stand. The density of yew regeneration was greater in 'Bogdanieckie Cisy' than in 'Cisy Rokickie'; the number of yew seedlings was 5000 individuals per hectare in 'Bogdanieckie Cisy' and 3332 individuals per hectare in 'Cisy Rokickie'. The vitality of yew regeneration was better under the beech-pine canopy in 'Bogdanieckie Cisy' reserve than in 'Cisy Rokickie'. Yew regeneration is grazed in the 'Cisy Rokickie' reserve even though the fence. The forest floor influenced the amount of yew regeneration; the greater cover of herbs the lower the density of yew regeneration. The presence of yew in all phases (from seedlings to small trees) that regeneration processes continue in both reserves.
\end{abstract}

Key words: yew conservation, stand structure, natural regeneration, yew morphology, Pomerania

\section{Introduction}

European yew (Taxus baccata L.) is considered to be endangered in central and eastern Europe, and also in Poland (Thomas, Polwart 2003). In our country, yew reaches the eastern boundary of its distribution area (Namvar, Spethmann 1986; Król, Gołąb 1996). Most yew stands are located at Pojezierze Pomorskie (Pomeranian Lakeland), Śląsk (Silesia), Małopolska (Lesser Poland), Podkarpacie regions and in Świętokrzyskie Mountains. T. baccata does not createpure stands. It grows in lower stand layers and in undergrowth within coniferous or mixed stands more commonly comprised of beech, fir, oak, hornbeam, lime and spruce (Król, Gołąb 1996). Currently, yew is strictly protected (Decree by the Minister of Environmental Protection, 1995).
Yew is an example of a species that has faced the threat of extinction due to extensive exploitation related to its exceptional use value. Yew protection started as early as $15^{\text {th }}$ century when king Władysław Jagiełło introduced yew protection in the Warta Statute in 1423 (Król, Gołąb 1996). Legal protection of yew has been initiated right after resumption of independence in 1918. Although yew was included in the first 'Nature protection law' of 1934, formally it was covered by strict protection only in 1946 based on the decree that introduced the protection of some plant species (Dz. U. RP, nr 70, poz. 384 z 1946 r.).

Yew has almost disappeared from our forests. The results of the evaluative study conducted by Sokołowski et al. (2000) indicated that only 6057 yew trees are left in the national forests. Most of them grow in nature 
reserves created for the purpose of yew protection. Previous research of T. baccata in Poland concentrated on studying yew quantity and population structure in nature reserves (Iszkuło 2001; Głowacka et al. 2002; Bodziarczyk, Zator 2004; Bodziarczyk, Rużyło 2007; Kmiecik 2009). There were also studies researching lack of yew regeneration in nature reserves (Kościelny, Król 1965, 1970). So far, there are almost no elaborate studies looking at stand structure of yew reserves and its influence on yew regeneration.

The goal of the current study was to research stand structure of the reserves created for yew protection for describing the quantity, vitality and growth conditions of natural yew regeneration, and investigating the threats affecting yew regeneration.

\section{Study area}

The research was conducted in two nature reserves located in the Pomorze (Pomerania) region. The 'Bogdanieckie Cisy' reserve with the area of 21.24 ha is located in the Bogdaniec Forest District (subdistrict Lubno). It was created through the initiative of the forest district manager Zygmunt Cichocki, with the collaboration of Prof. Stanisław Król in the year 2000 with the objective of preserving for scientific and educational purposes one of the most numerous yew populations in Poland located within its eastern boundary of distribution area. This yew population presumably originated naturally from the seeds of several yew trees growing near the rural manor-house. The site is mostly occupied by the beech forest of Fagetalia type with Asperula odorata in ground cover and partially by the mixed pine forest of Querco roboris Pinetum type. According to the regional classification of Kondracki (2002), the reserve is located in the macroregion of Pojezierze Południowopomorskie (South Pomeranian Lakeland) (314.6/7) and mezoregion of Równina Gorzowska (Gorzowska Plain) (314.61), while according to the regional nature and forest classification it is situated in the First Battycka province and mezoregion of Gorzowska Plain (b). Forests of the reserve are located on fresh mixed broadleaved forest (LMśw) and fresh mixed coniferous forest (BMśw) habitat types placed on brown ferruginous soils originating from sandy loams.

The 'Bogdanieckie Cisy' reserve with the area of 17.4 ha is located in Goleniowska Forest within the area of Rokita Forest District on the Natura 2000 site (Ostoja Goleniowska PLH320013). The reserve was organised with the initiative of Prof. Stanisław Król in 1987 in order to preserve the most numerous yew population in Poland as well as to protect other plant species, such as Lonicera periclymenum and Galanthus nivali. The reserve is covered by acidophilic oak forest of Betulo pendulae-Quercetum roboris type. Forests of the Rokita Forest District are located in the Bałtycka province and the Nizina Szczecińska (Szczecińska Lowland) section I.2 (according to the regional nature and forest classification). As per the Kondracki classification (2002), forests of the Rokita Forest District are situated in the Goleniowska Plain mezoregion (313.25), which is a part of the Pobrzeże Szczecińskie (Szczecińskie sea coast) macroregion. Forests of the reserve grow on the fresh mixed coniferous forest habitat type (BMśw), former agricultural podsolic soil, and fresh loamy sand or loose sand. Yew trees regenerated naturally from several parent trees planted in the middle of $19^{\text {th }}$ century. In some places, following the advice of the scientific curator of the reserve, Prof. Król, thinning of tree stands was conducted (with the agreement of the regional nature conservation authority), which resulted in growth acceleration and improvement of vitality of the remaining individuals.

The average temperature in the region is $7.5^{\circ} \mathrm{C}$; the average January temperature is $-2.3^{\circ} \mathrm{C}$, and the average July temperature is $16.9^{\circ} \mathrm{C}$. The growing season starts on April $2^{\text {nd }}$ and ends on September $3^{\text {rd }}$. Precipitation during the growing season is $411 \mathrm{~mm}$, and annual precipitation is $629 \mathrm{~mm}$ (Lorenz 1993).

\section{Methods}

Stand structure and natural regeneration were studied at concentric circular plots. In 2011, the nature reserves were divided into rectangular network measuring $75 \times 75$ $\mathrm{m}$ in the 'Bogdanieckie Cisy' reserve and $50 \times 75 \mathrm{~m}$ in the 'Cisy Rokickie' reserve where 30 sample plots were established in each reserve. The whole reserve area was used as a research site. Diameter at breast height of all trees and tree vitality were measured within the circle plot of $250 \mathrm{~m}^{2}(r=8.92 \mathrm{~m})$. Natural regeneration was evaluated on the $10 \mathrm{~m}^{2}(r=1.78 \mathrm{~m})$ plots. The vitality measurements included height of all trees, dbh for trees higher than $1.3 \mathrm{~m}$, vitality evaluation, degree of damage (from abiotic and biotic factors) and number of stems in yew trees growing within study plots. Geographical coordinates were established for plot centres using GPS. Additionally, percent cover of ground litter, mosses, lichens, herbs, seedlings and saplings was defined for each experimental plot. 
The research established threeheight classes of natural regeneration: seedlings $(h \leq 0.5 \mathrm{~m})$, short saplings $(h \quad 0.5-1.3 \mathrm{~m})$ and tall saplings $(h>1.3 \mathrm{~m}$ i $d \leq 7 \mathrm{~cm})$. Moreover, lower stand layer $(d: 7-12 \mathrm{~cm})$ was described.

The following vitality classes were assigned to regeneration: 1 . highly vital, 2 . normally vital, 3 . weakened (potentially valuable), 4 . dying and 5 . dead.

\section{Statistical analysis}

The Mann-Whitney U test $(\alpha=0.05)$ was used for comparing stand and ground cover structure in two nature reserves. The analysis included such elements as percent cover of ground litter, mosses, lichens, plants, seedlings and saplings. Selection of such non-parametric test was necessary due to the non-fulfilment of assumptions on normality of variable distributions (according to Shapiro-Wilk test). The following statistical calculation was used for verification of hypothesis on the lack of differences in ground cover between the studied nature reserves:

$$
Z=\frac{R_{1}-R_{2}-\left(n_{1}-n_{2}\right) \frac{n+1}{2}}{\sqrt{\frac{n_{1} n_{2}(n+1)}{3}}}
$$

where:

$R_{1}-$ sum of the ranks for reserve 1 ,

$R_{2}$ - sum of the ranks for reserve 2 ,

$n$-total number of observations,

$n_{1}-$ number of observations in reserve 1 ,

$n_{2}-$ number of observations in reserve 2 .

When tied observations were present, correction for ties was implemented. Moreover, for all components of forest floor $(\alpha=0.05)$, Spearman's rank correlation with the number of yew seedlings was used (assigning ranks to yew regeneration).

Species composition in both reserves was compared using Pearson's $\chi 2$ test. Preliminary data evaluation eliminated those species which appeared in researched stands as single individuals. Remaining data were combined into contingency table and Pearson's chisquared test statistic was calculated $(\alpha=0.05)$. Because expected cell frequency was higher than 5 , the Yates correction was not used (Stanisz 2006).

Significance of differences between vitality of natural regeneration in the two studied reserves and between tree vitality (in upper stand layers) was tested by the Mann-Whitney $U$ test $(\alpha=0.05)$.

Statistical analysis was conducted using Statistica 8.0 software.

\section{Results}

\section{Stand structure}

The share of various tree species was significantly different in the two nature reserves (Pearson's $\chi^{2}$ test: $\chi 2=155.8120 ; p=0.0000)$. The 'Cisy Rokickie' reserve was dominated by Scots pine ( $84 \%$ of tree basal area). Quantity of remaining tree species was low (Table 1). Yew trees could be distinguished in the lower stand layers; however, their share was low. Yew dominated the diameter class of 7-12 cm (Table 2). Scots pine dominated the 'Bogdanieckie Cisy' reserve ( $72 \%$ of tree basal area). There was also considerable share of beech and oak. Number of yew trees in lower stand layers was not much lower than in the 'Cisy Rokickie' reserve. Yew dominated the 7-12 cm diameter class, where oak and beech were also present.

Table 1. Number, basal area and percentage of trees in investigated reserves 'Cisy Rokickie'and 'Bogdanieckie Cisy'

\begin{tabular}{|c|c|c|c|c|c|c|c|c|c|c|c|c|c|c|c|}
\hline \multicolumn{16}{|c|}{ Tree species* } \\
\hline Feature & $\mathrm{Bk}$ & $\mathrm{Brz}$ & Cis & $\mathrm{Db}$ & $\mathrm{Gb}$ & Jrz & $\mathrm{JW}$ & Kru & Lp & Os & So & Św & Lsz & Other & Total \\
\hline \multicolumn{16}{|c|}{ Cisy Rokickie } \\
\hline $\mathrm{N} / \mathrm{ha}$ & 9.3 & 72.0 & 66.7 & 5.3 & & 2.7 & 1.3 & 2.7 & & & 277 & 24.0 & 13.3 & 6.67 & 481.37 \\
\hline $\mathrm{G}\left(\mathrm{m}^{2} / \mathrm{ha}\right)$ & 0.06 & 2.22 & 0.55 & 0.03 & & 0.02 & 0.01 & 0.01 & & & 23.9 & 1.08 & 0.07 & 1.8 & 29.72 \\
\hline $\mathrm{F}(\%)$ & 0.2 & 7.5 & 2.0 & 0.1 & & 0.1 & 0.05 & 0.05 & & & 80 & 4 & 0.2 & 6 & 100 \\
\hline \multicolumn{16}{|c|}{ Bogdanieckie Cisy } \\
\hline $\mathrm{N} / \mathrm{ha}$ & 117 & 17 & 61.0 & 70.7 & 4.00 & 6.7 & 6.7 & & 1.3 & 5.3 & 264 & & & 1.3 & 555.66 \\
\hline $\mathrm{G}\left(\mathrm{m}^{2} / \mathrm{ha}\right)$ & 6.96 & 0.60 & 0.56 & 1.51 & 0.03 & 0.04 & 0.20 & & 0.02 & 0.08 & 25.7 & & & 0.03 & 35.74 \\
\hline$F(\%)$ & 19.4 & 2 & 2 & 4 & 0.1 & 0.1 & 1 & & 0.1 & 0.2 & 71 & & & 0.1 & 100 \\
\hline
\end{tabular}

Bk - Fagus silvatica; Brz - Betula pendula; Cis - Taxus baccata;Db - Quercus sp.; Gb - Carpinus betulus; Jrz - Sorbus aucuparia; Jw - Acer pseudoplatanus; Kru - Frangula alnus; Lp - Tilia cordata; Os - Populus tremula; So - Pinus sylvestris; Sw - Picea abies; Lsz - Corylus avellana 
Table 2. Number and share of trees in lower stand layer ( $\mathrm{dbh} 7-12 \mathrm{~m})$ in investigated reserves 'Cisy Rokickie' and 'Bogdanieckie Cisy' (symbols of species as in Table 1)

\begin{tabular}{|c|c|c|c|c|c|c|c|c|c|c|c|c|c|}
\hline Feature & $\mathrm{Bk}$ & Brz & Cis & $\mathrm{Db}$ & $\mathrm{Gb}$ & Jrz & $\mathrm{JW}$ & Lp & So & Św & Lsz & Os & Other \\
\hline \multicolumn{14}{|c|}{ Cisy Rokickie } \\
\hline $\mathrm{N} / \mathrm{ha}$ & 6 & 10 & 52 & 4 & & 2 & 1 & & & 1 & 10 & & 2 \\
\hline$\%$ & 7 & 11 & 59 & 5 & & 2 & 1 & & & 1 & 11 & & 3 \\
\hline \multicolumn{14}{|c|}{ Bogdanieckie Cisy } \\
\hline $\mathrm{N} / \mathrm{ha}$ & 12 & 6 & 38 & 29 & 3 & 5 & 1 & & 1 & & & 2 & \\
\hline$\%$ & 13 & 6 & 39 & 30 & 3 & 3 & 3 & & 3 & & & 2 & \\
\hline
\end{tabular}

* Symbols as in Table 1

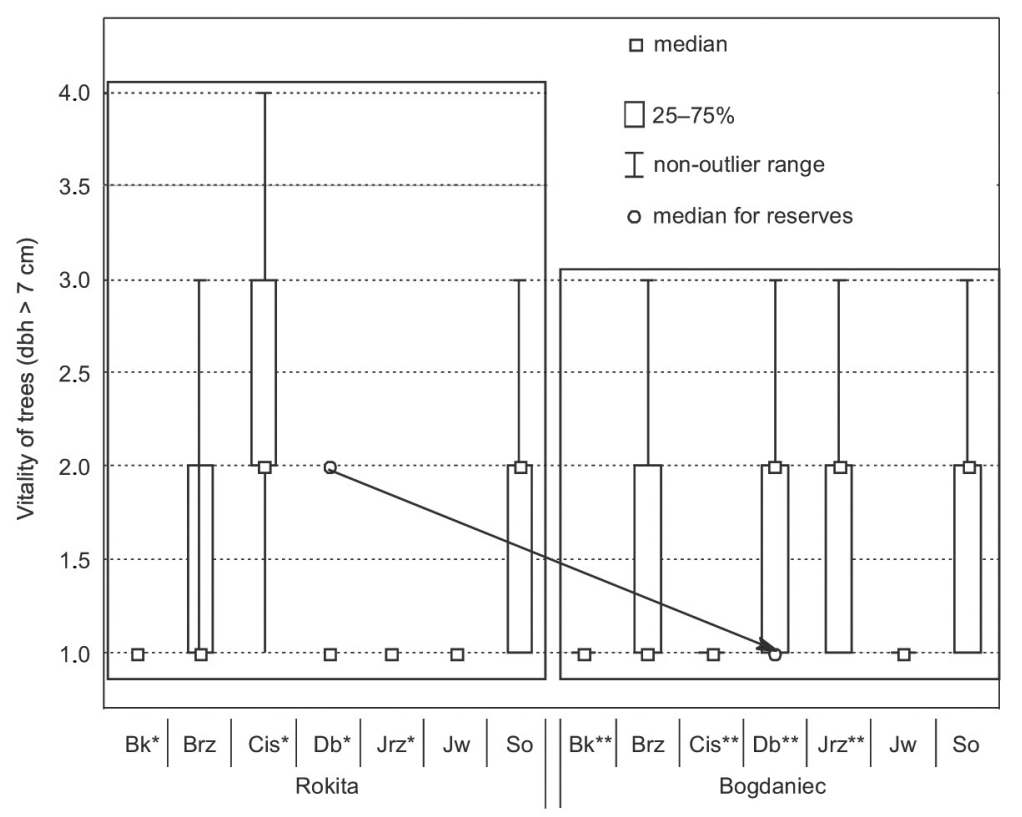

Figure 1. Vitality of trees in investigated reserves. Asterisks denote species with statistical differences $(\alpha=0.05)$. Arrow denotes median for reserves (Symbols of species as in Table 1).

\section{Tree vitality}

Tree vitality significantly differed in the studied nature reserves (the Mann-Whitney U test, $\left.Z_{\text {corrected }}=-4.90124 ; p=0.0000\right)$. The median for the 'Cisy Rokickie' reserve was equal to 2 , while the median for the nature reserve in the Bogdaniec Forest District was equal to 1 . Yew had the lowest vitality in the 'Cisy Rokickie' reserve, giving way to all other species in that reserve, and also in the combined classification for both reserves. In the upper stand layers, pine and birch had lower vitality. Tree vitality in the 'Bogdanieckie Cisy' reserve was high. Yew vitality was also very high. Pine, birch and ash vitality was similar to that in the 'Cisy Rokickie' reserve (Fig. 1).

\section{Ground cover}

The share of mosses, litter, herbs and ferns was significantly different in the compared reserves (MannWhitney $U$ test, $\alpha=0.05)$. Herbs were dominant (62.8\%) in the 'Cisy Rokickie' reserve (Table 4). There was also significant share of ferns $(9.2 \%)$. Ground with no vegetation cover and no tree regeneration was prevailing in the 'Bogdanieckie Cisy' reserve (93.3\%). The number of seedlings was very low in both reserves. Larger 
Table 3. Share of trees in vitality classes and average vitality of particular trees in investigated reserves 'Cisy Rokickie'(CR) and 'Bogdanieckie Cisy'(BC)

\begin{tabular}{|c|c|c|c|c|c|c|c|c|c|c|}
\hline \multirow{2}{*}{ Species* } & \multicolumn{2}{|c|}{1} & \multicolumn{2}{|c|}{2} & \multicolumn{2}{|c|}{3} & \multicolumn{2}{|c|}{4} & \multicolumn{2}{|c|}{ Average } \\
\hline & CR & $\mathrm{BC}$ & $\mathrm{CR}$ & $\mathrm{BC}$ & CR & $\mathrm{BC}$ & $\mathrm{CR}$ & $\mathrm{BC}$ & $\mathrm{CR}$ & $\mathrm{BC}$ \\
\hline Bk & 100 & 90 & & 9 & & 1 & & & 1.0 & 1.1 \\
\hline Brz & 59 & 69 & 30 & 31 & 11 & & & & 1.5 & 1.3 \\
\hline Cis & 35 & 94 & 48 & 4 & 13 & 2 & 3 & & 1.9 & 1.1 \\
\hline Other & 71 & 100 & 29 & & & & & & 1.3 & 1.0 \\
\hline $\mathrm{Db}$ & 100 & 45 & & 45 & & 9 & & & 1.0 & 1.6 \\
\hline Jrz & 100 & 60 & & 40 & & & & & 1.0 & 1.4 \\
\hline $\mathrm{JW}$ & 100 & 100 & & & & & & & 1.0 & 1.0 \\
\hline Kru & & & 100 & 100 & & & & & 2.0 & 2.0 \\
\hline So & 47 & 39 & 43 & 47 & 10 & 10 & & 4 & 1.6 & 1.8 \\
\hline Lsz & 100 & & & & & & & & 1.0 & \\
\hline $\mathrm{Lp}$ & & & & 100 & & & & & & 2.0 \\
\hline $\mathrm{Gb}$ & & 100 & & & & & & & & 1.0 \\
\hline Os & & 100 & & & & & & & & 1.0 \\
\hline Św & 100 & & & & & & & & 1.0 & \\
\hline
\end{tabular}

* Symbols as in Table 1

Table 4. Average ground cover in reserves 'Cisy Rokickie' and 'Bogdanieckie Cisy'and results of Mann-Whitney test

\begin{tabular}{ccccc}
\hline \hline Ground cover & Cisy Rokickie & Bogdanieckie Cisy & $\mathrm{Z}_{\text {corrected }}$ & $P$ \\
\hline Litter & 18.7 & 93.3 & -6.1205 & 0.0000 \\
Mosses & 28 & 0.3 & 4.74028 & 0.0000 \\
Ferns & 9.2 & 2.7 & 4.10873 & 0.0000 \\
Herbs & 62.8 & 1.7 & 5.45868 & 0.0000 \\
Seedlings & 0.2 & 0.7 & -1.71982 & 0.0855 \\
Saplings & 8 & 2.8 & 1.11856 & 0.2633 \\
\hline \hline
\end{tabular}

number of saplings was found in the 'Cisy Rokickie' reserve $(8 \%)$ than in the 'Bogdanieckie Cisy' reserve (2.8\%), but these value differences were not significant (Mann-Whitney U test) (Table 4).

Spearman's rank correlation demonstrated statistically significant coexistence of seedlings and natural yew regeneration $(0.537701, \alpha=0.05)$. It also showed negative correlation between herb appearance and yew regeneration $(-0.271689, \alpha=0.05)$. All other correlations between quantity of natural yew regeneration and land cover by litter, mosses and ferns were statistically insignificant $(\alpha=0.05)$ and were equal to $0.233917,-0.148697$ and 0.067462 , respectively.

\section{Quantity of natural regeneration}

The number of seedlings was high in both reserves (Table 5). Larger number of seedlings per unit area was found in the 'Bogdanieckie Cisy' reserve (5000/ha) than in the 'Cisy Rokickie' reserve (3332/ha). The number of yew seedlings in the 'Cisy Rokickie' reserve was low $(133 /$ ha). Ash was dominant in the seedling growth phase in the 'Bogdanieckie Cisy' reserve (1433/ha), while quantity of yew seedlings was only slightly lower (1167/ ha). The number of trees in the sapling growth phase was similar in both reserves. Yew trees were scarce in sapling phase of both 'Cisy Rokickie' and 'Bogdanieckie Cisy' reserves. The phase of tall saplings had significantly larger numbers of yew trees in the 'Cisy Rokickie' reserve than in 'Bogdanieckie Cisy' reserve. Species richness in regeneration phases was high in both studied areas. In total, 14 species of trees and shrubs were found in both reserves.

\section{Vitality of natural regeneration}

Vitality of natural regeneration was high in both reserves. The Mann-Whitney $U$ test indicated significant statistical differences between vitality 
Table 5. Number (N/ha) of particular species of regeneration in height classes

\begin{tabular}{|c|c|c|c|c|c|c|}
\hline \multirow{2}{*}{ Species* } & \multicolumn{3}{|c|}{ Cisy Rokickie } & \multicolumn{3}{|c|}{ Bogdanieckie Cisy } \\
\hline & $h \leq 0.5 \mathrm{~m}$ & $0.5<h \leq 1.3 \mathrm{~m}$ & $h>1.30 \mathrm{~m}$ & $h \leq 0.5 \mathrm{~m}$ & $0.5<h \leq 1.3 \mathrm{~m}$ & $h>1.30 \mathrm{~m}$ \\
\hline $\mathrm{Bk}$ & & & 20 & 767 & 43 & 223 \\
\hline $\mathrm{Brz}$ & & & 30 & & & 3 \\
\hline Cis & 133 & 13 & 197 & 1167 & 30 & 130 \\
\hline Czm & 33 & 13 & 27 & 900 & 147 & 43 \\
\hline $\mathrm{Db}$ & 600 & 77 & 333 & & 3 & 3 \\
\hline Jrz & 333 & 47 & 280 & 200 & 47 & 120 \\
\hline $\mathrm{JW}$ & 200 & 103 & 170 & 1433 & 130 & 170 \\
\hline $\mathrm{K} 1$ & 33 & 7 & & 400 & 20 & 43 \\
\hline Kru & 1500 & 180 & 327 & 100 & 7 & 10 \\
\hline So & 433 & & 3 & & & \\
\hline Lsz & & & 3 & & & \\
\hline $\mathrm{Wz}$ & & & & & 7 & \\
\hline Os & & & & 33 & 3 & 13 \\
\hline $\mathrm{Gb}$ & & & & & & 3 \\
\hline Lp & 67 & 7 & 3 & & 3 & \\
\hline Głóg & & & 3 & & & 3 \\
\hline Trz & & & 3 & & & \\
\hline
\end{tabular}

* Symbols of species as in Table 1

Table 6. Medians and quartiles of vitality on 30 circular plots for particular tree species (seedlings, short saplings, high saplings) (symbols of species as in Table 1)

\begin{tabular}{|c|c|c|c|c|c|c|c|c|c|c|c|c|}
\hline \multirow{2}{*}{ Species* } & \multicolumn{4}{|c|}{ Seedlings } & \multicolumn{4}{|c|}{ Short saplings } & \multicolumn{4}{|c|}{ Tall saplings } \\
\hline & $\mathrm{N}$ & Q25 & Median & Q75 & $\mathrm{N}$ & Q25 & Median & Q75 & $\mathrm{N}$ & Q25 & Median & Q75 \\
\hline Rokita & 98 & & & & 132 & & & & 172 & & & \\
\hline Cis & 4 & 1 & 1 & 1 & 4 & 2 & 2.5 & 3 & 0 & & & \\
\hline Kru & 46 & 1 & 2 & 2 & 52 & 2 & 2 & 2 & 56 & 1 & 2 & 2 \\
\hline So & 13 & 1 & 1 & 1 & & & & & & & & \\
\hline $\mathrm{Bk}$ & 0 & & & & 0 & & & & 1 & 2 & 2 & 2 \\
\hline $\mathrm{Jrz}$ & 10 & 2 & 2 & 3 & 13 & 2 & 2 & 3 & 39 & 2 & 2 & 2 \\
\hline $\mathrm{Czm}$ & 1 & 2 & 2 & 2 & 4 & 1 & 1 & 1.5 & 5 & 1 & 1 & 1 \\
\hline $\mathrm{Kl}$ & 1 & 1 & 1 & 1 & 2 & 1 & 2 & 3 & 0 & & & \\
\hline Jw & 4 & 1.5 & 2 & 2 & 32 & 1 & 1 & 2 & 26 & & & 1 \\
\hline $\mathrm{Db}$ & 17 & 1 & 2 & 3 & 23 & 2 & 2 & 3 & 44 & & & 2 \\
\hline Os & 0 & & & & 0 & & & & 0 & & & \\
\hline Lp & 2 & 2 & 2 & 2 & 2 & 1 & 1 & 1 & 1 & & & 1 \\
\hline Bogdaniec & 151 & & & & 130 & & & & 90 & & & \\
\hline Cis & 35 & 1 & 1 & 1 & 9 & 1 & 1 & 1 & 3 & & & 1 \\
\hline Kru & 3 & 1 & 1 & 3 & 2 & 2 & 2 & 2 & 1 & & & 1 \\
\hline So & 0 & & & & 0 & & & & 0 & & & \\
\hline $\mathrm{Bk}$ & 23 & 1 & 1 & 1 & 13 & 1 & 1 & 1 & 21 & & & 2 \\
\hline Jrz & 6 & 1 & 1 & 1 & 14 & 1 & 1.5 & 2 & 8 & & & 2.5 \\
\hline $\mathrm{Czm}$ & 28 & 1 & 1 & 2 & 44 & 1 & 1 & 1 & 12 & & & 2.5 \\
\hline $\mathrm{K} 1$ & 12 & 1 & 1 & 1 & 6 & 1 & 1.5 & 3 & 9 & & & 1 \\
\hline JW & 43 & 1 & 1 & 1 & 39 & 1 & 1 & 2 & 35 & & & 1 \\
\hline $\mathrm{Db}$ & 0 & & & & 1 & 3 & 3 & 3 & 0 & & & \\
\hline Os & 1 & 1 & 1 & 1 & 1 & 2 & 2 & 2 & 1 & 2 & 2 & 2 \\
\hline Lp & 0 & & & & 1 & 2 & 2 & 2 & 0 & & & \\
\hline
\end{tabular}

\footnotetext{
* Symbols of species as in Table 1
} 


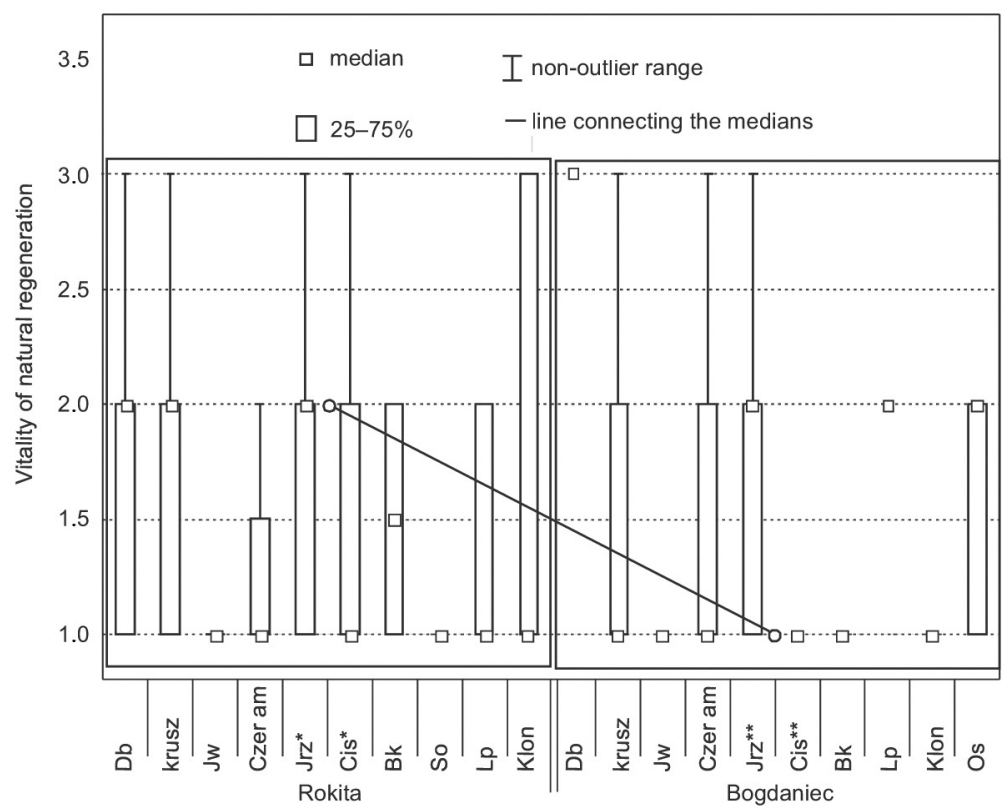

Figure 2. Median of natural regeneration vitality. Species vitality with asterisk differs statistically in compared reserves

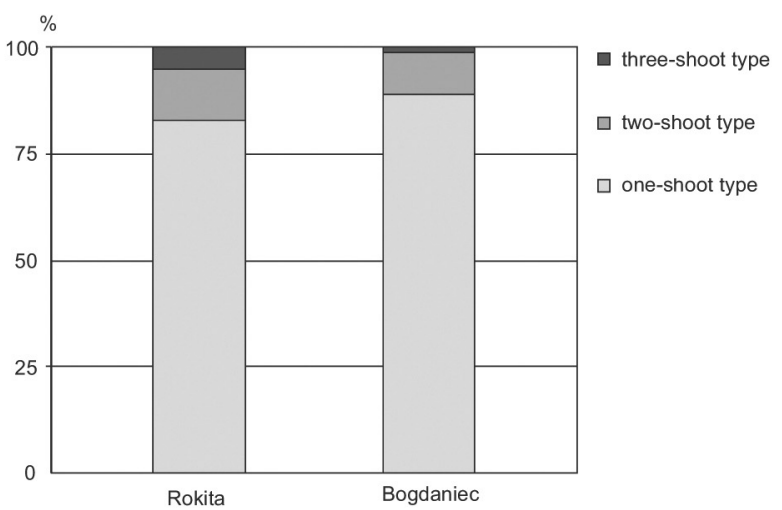

Figure 3. Share of particular types of yew in reserves Cisy Rokickie and Bogdanieckie Cisy

of natural regeneration in both the studied reserves $(Z=9.40020 ; p=0.0000 ;$ Fig. 2). Vitality median for natural regeneration was equal to 1 in the 'Bogdanieckie Cisy' reserve, and 2 in the 'Cisy Rokickie' reserve. It is important to emphasise the very high yew vitality in the seedling phase in both reserves (Table 6).

Yew vitality in the short sapling phase was lower in the 'Cisy Rokickie' reserve (vitality median of 2.5) than in 'Bogdanieckie Cisy' reserve. Yew vitality in the tall saplings phase was equal to 1 in the 'Bogdanieckie Cisy' reserve. There were no tall yew saplings in the 'Cisy Rokickie' reserve.

\section{Yew crown shape}

Yew trees with one stem were more common in both nature reserves (Fig. 3). The share of two- and threestem yews was low.

\section{Discussion}

Yew trees more commonly occur in stands comprised of Quercus, Tilia, Acer, Carpinus, Picea and Abies tree species (Stypiński et al. 1984; Iszkuło, Boratyński 2004), while in analysed stands, pine was the dominant species. The optimal conditions for yew occur in Cephalentero-Fagion stands (Ellenberg et al. 1991; Matuszkiewicz 2002). In central Europe, yew can be found in forest stands of Caprinion betuli and Quercionrobori-petraeae types (Sokołowski 1970). Due to larger share of broadleaf species (larger tree basal area), better conditions for yew regeneration exist in the 'Bogdanieckie Cisy' reserve, which is confirmed by higher quantity of yew seedlings, despite the fact that low light penetration at soil level resulted in domination of detritus on forest floor.

Yew $(d: 7-12 \mathrm{~cm})$ was dominant $(59 \%)$ in the lower layers of forest stands in 'Cisy Rokickie' reserve, while oak and beech dominated (41\%) the lower layers of the 'Bogdanieckie Cisy' reserve. Here the forest type was close to the Fagetalia type, while in 'Cisy Rokickie' 
reserve, the forest type was identified as acidophilic oak forest. The number of yew trees was higher in the 'Cisy Rokickie' reserve, where yew grows within the fresh mixed coniferous forest (BMśw) habitat type. According to Zaręba (1984), optimal ecological conditions for T. baccata could be found at the borderline of moist broadleaved forest, ash-alder swamp forest and fresh broadleaved forest habitat types. Therefore, habitats of the 'Bogdanieckie Cisy' reserve appear to be more suitable for yew.

The location of both reserves at the Pojezierze Pomorskie favours progressive development of yew populations. Both reserves can be characterised by high amounts of atmospheric precipitation (influence of marine climate). Yew prefers conditions having Atlantic characteristics (Ellenberg et al. 1991; Zarzycki et al. 2002; Iszkuło, Boratyński 2005). In cases when low soil humidity is compensated by air humidity, yew can also regenerate and grow well. Such conditions could be found in the Rokita Forest District.

Ground cover has significant influence on natural regeneration of trees. Much worse conditions for regeneration existed in 'Cisy Rokickie' reserve, where $63 \%$ of area was covered with herbal vegetation and ferns. In the 'Bogdanieckie Cisy' reserve, $93 \%$ of area was covered by detritus, and only $2 \%$ by ground vegetation. As a consequence, the quantity of yew seedlings was different, and in the 'Bogdanieckie Cisy' reserve it was nine times higher than in 'Cisy Rokickie' reserve. The research conducted by various authors indicates that yew regeneration is negatively affected by competing vegetation of ground cover (Głowacka 2005; Hylla 2011). Yew seedlings can tolerate competition from ground vegetation and can grow in shade for some time, while improved light regime results in accelerated growth. However, when seedlings find themselves in very dark conditions under other species, they gradually die because yew grows very slowly and is unable to compete with other species for natural resources (Iszkuło, Boratyński 2005).

The number of consequent phases of yew regeneration indicates continuity of yew regeneration process in both nature reserves. All regeneration phases were present from seedlings through saplings to young trees. Yew is an element of the lower forest layers. It does not create pure stands (Iszkuło, Boratyński 2004).

Vitality of yew trees in upper stand layers was very good in both nature reserves. It can probably be an effect of favourable moisture and thermal conditions existing in these forest districts. Average values of hydrological and thermal coefficient during the vegetation season at the time of research were higher than long-term data (Raport o stanie lasów, 2010), suggesting that relations between air temperature and precipitation quantity were beneficial for tree growth in the north-western region of Poland. The study of tree defoliation (Raport o stanie lasów, 2010) shows that the most vigorous stands in Poland grow in the Regional Directorate of the State Forests in Szczecin. The lowest share of healthy trees is found in pine stands. Average vitality of pine trees in both nature reserves was lower than 2 . Such low vitality could be due to pine tree age. The vitality of T. baccata trees with $\mathrm{d}>7 \mathrm{~cm}$ was low in the 'Cisy Rokickie' reserve in spite of better light penetration associated with transparent pine crowns, lower basal area and absence of lower stand layers. Such low yew vitality could be explained by the presence of Sphaerulina taxi (Cke.) Massee i Diplodia taxi De Not. fungi on needles (information provided by forest district).

In both reserves, yew trees with single stem were more common. Share of yew trees with several stems was low. Similar results were obtained by Hylla (2011) during the research conducted in the 'Cisy nad Liswartą' reserve and by Bodziarczyk, Rużyło (2007) studying populations in 'Cisy na Górze Jawor' reserve.

Canopy density influences the number of yew trees. The largest number of yew trees usually sprouts under the canopy of coniferous trees, such as Scots pine, Norway spruce and European larch (Iszkuło, Boratyński 2004). Similar situation was observed in both the studied reserves, where yew population was quite high compared with other reserves (Sokołowski 2000). Survival rate and quantity of yew trees arehigher under the canopy of broadleaf trees (Iszkuło, Boratyński 2004), which was confirmed by our research. The number of yew seedlings was much higher in the 'Bogdanieckie Cisy' reserve than in 'Cisy Rokickie' reserve.

According to the inventory conducted by the Forest Research Institute, the number of yew trees per hectare was higher in the 'Cisy Rokickie' reserve, where it was 5500, than in the 'Bogdanieckie Cisy' reserve, where it was 2056 (Sokołowski 2000). As reported by the forest inventory conducted by the Forest District, there were 1732 individuals in the 'Bogdanieckie Cisy' reserve Reserve and 4014 individuals in the 'Cisy Rokickie' reserve. The above inventory covered all yew individuals and therefore their number was higher than in the research discussed, which presented the average number of trees per unit area (hectare).

Yew regeneration was present in the studied reserves and its number was higher than in other reserves. 
Problems with natural regeneration of yew have been observed for a long time not only in Poland, but also in other countries (Mańka et al. 1968; Hulme 1996; Garcia et al. 2000; Sokołowski 2000; Kmiecik 2009). For example, yew regeneration count in the reserve located in Ukrainian Carpathians was only 10161268 individuals per hectare (Iszkuło et al. 2005). Yew populations in Wierzchlas (Król 1975) as well as 'Zdroje' (Friedrich 2008) or 'Cisowy Jar' (Iszkuło 2001) reserves can illustrate the problems existing with preservation of natural yew regeneration.

Yew can grow in unfavourable light conditions and compete with other trees for some period of time (Iszkuło, Boratyński 2005). With the improvement of light regime, yew trees increase the number of needles and regenerate their crowns. Efficient thinnings can benefit yew growth, which can be illustrated by yew trees in' Bogdanieckie Cisy' reserve, where thinning exposing T. baccata was conducted several years ago. The length of needles, their colour (dark green), crown shape and above all yew vitality are currently very high. On the other hand, yew crown shape, needle length and colour (greyish green) in the 'Cisy Rokickie' reserve are worse than those in the Bogdaniec Forest District. T. baccata reacts negatively to sudden change in above crown cover and increase in light exposure as well as thermal regime (Iszkuło, Boratyński 2005). Amount of light reaching forest floor was higher in the 'Cisy Rokickie' than in 'Bogdanieckie Cisy' reserve due to smaller stand basal area and absence of lower stand layer. However, there were no detailed analyses of light condition. The specific amount of light necessary for the orderly growth of yew trees requires further research.

\section{Conclusions}

European yew has good growth conditions in both reserves located in the Pomorze region, which is confirmed by the population vitality and presence of natural regeneration.

Number of individuals within consequent growth phases indicates continuity of regeneration process of yew in both reserves.

Yew vitality was better in forest stands with higher share of broadleaf species in forest canopy ('Bogdanieckie Cisy' reserve).

Quantity of yew regeneration depends on competition from forest ground cover. The higher the ground vegetation cover, the lower is the number of yew regeneration.

\section{Acknowledgements}

The authors would like to thank the Forest District Managers Mr. Tomasz Szeszycki and Mr. Piotr Pietkun as well as the staff of the Forest Districts Rokita and Bogdaniec for their generosity and help with their research.

\section{References}

Bodziarczyk J., Zator A. 2004. Rozmieszczenie, struktura i warunki występowania populacji cisa pospolitego ( $T a-$ xus baccata L.) w paśmie Łysej Góry w Beskidzie Niskim [Distribution, structure and habitat conditions of the population of European yew Taxus baccata L. in the Lysa Góra massif of the Beskid Niski range]. Acta Agraria et Silvestria, 42: 1-22.

Bodziarczyk J., Rużyło T. 2007. Warunki występowania, struktura oraz stan zdrowotny populacji cisa pospolitego (Taxus baccata L.) w rezerwacie przyrody „Cisy na Górze Jawor" w Bieszczadach [Conditions of occurrence, structure, and health status of the population of common yew Taxus baccata L. in the „Cisy na Górze Jawor” nature reserve, Bieszczady Mts, Poland]. Roczniki Bieszczadzkie, 15: $163-179$.

Ellenberg H., Weber H.E., Dull R., Wirtth V., Werner W., Paulissen D. 1991. Zeigerwerte der Grefasspflanzen Mit-teleuropas. Scripta Geobotanica, 18: 1-122.

Friedrich S. 2008. Struktura drzewostanu w rezerwacie cisowym „Zdroje” w Szczecinie [Stand structure in the „Zdroje" common yew nature reserve in Szczecin]. Sylwan, 152, 8: 25-34.

Garcia D., Zamora R., Hodar J., Gomez J.M., Castro J. 2000. Yew (Taxus baccata L.) regeneration facilitated by flesyfruited shrubs in Mediterranean environments. Biological Conservation, 95: 31-38.

Głowacka M. 2005. Ekologiczne uwarunkowania występowania cisa pospolitego Taxus baccata L. w Polsce. Praca doktorska. Katowice, Uniwersytet Śląski.

Głowacka M., Michalski G., Gancarczyk-Gola M., Gola T. 2002. The common yew (Taxus baccata L.) population in Wysoka Lelowska Kępino near Żarki in Southern Poland. Acta Biologica Silesiana 36 (53): 125-137.

Hulme P. 1996. Natural regeneration of yew (Taxus baccata L.): microsite, seed or herbivore limitation? Journal of Ecology, 84: 583-861.

Hylla W. 2011. Struktura naturalnej populacji cisa pospolitego Taxus baccata L. w rezerwacie „Cisy nad Liswartą”. Praca Doktorska. SGGW, Warszawa.

Iszkuło G. 2001. The yew (Taxus baccata L.) of the Cisowy Jar reserve near Olecko. Dendrobiology, 46: 33-37.

Iszkuło G., Boratyński A. 2004. Interaction between canopy tree species and European yew Taxus baccata (Taxaceae). Polish Journal of Ecology, 52, 4: 523-531. 
Iszkuło G., Boratyński A. 2005. Different age and spatial structure of two spontaneous subpopulations of Taxus baccata as a result of various intensity of colonization process. Flora, 200: 195-206.

Iszkuło G., Boratyński A., Diduch Y., Romaschenko K., Pryazhko N. 2005. Changes of population structure of Taxus baccata L. during 25 years in protected area (Carpathians, Western Ukraine). Polish Journal of Ecology, 53,1: 13-23.

Kmiecik M. 2009. Cis pospolity (Taxus baccata L.) w Górach Bardzkich - stan i tendencje rozwoju. Praca Doktorska. IDPAN, Kórnik.

Kondracki J. 2002. Geografia regionalna Polski, PWN, Warszawa. ISBN 83- 01-13897-1.

Kościelny S., Król S. 1965. Wstępne wyniki badań nad wpływem czynników warunkujących naturalne odnawianie się cisa. Roczniki WSR Poznań, 27: 101-107.

Kościelny S., Król S., 1970. Próby ustalenia czynników ekologicznych warunkujących naturalne odnawianie się cisa w rezerwatach. Prace Komisji Nauk Rolniczych i Komisji Nauk Leśnych PTPN, 30: 79-105.

Król S. 1975. Zarys ekologii. In: Cis pospolity. Warszawa-Poznań, PWN: 78-103.

Król S., Gołąb W. 1996. Bibliografia cisa pospolitego Taxus baccata L. w Polsce. Poznań, Wydawnictwo Sorus. ISBN8385599525.

Lorenc H. 1994. Symptomy zmian klimatu w strefach ograniczonych wpływów antropogennych. Materiaty Badawcze Instytut Meteorologii i Gospodarki Wodnej, Meteorologia, 19: 3-52.

Mańka K., Gierczak M., Prusinkiewicz Z. 1968. Zamieranie siewek cisa Taxus baccata L. w Wierzchlesie na tle zespołów saprofitycznych grzybów środowiska glebowego [The succumbing of yew-tree seedlings in Wierzchlas and the saprophytic fungi of the soil environment]. Prace Komisji Nauk Rolniczych i Leśnych PTPN, 25: 177-195.
Matuszkiewicz J. M. 2002. Zespoły leśne Polski. PWN, Warszawa. ISBN 8301134011.

Namvar K., Spethmann W. 1986. Die Eibe (Taxus baccata L.). Allgemeine Forst Zeitschrift fur Waldwirtschaft und Umweltvorsorge, 23: 568-571.

Raport o stanie lasów w Polsce 2009. 2010. Warszawa, CILP. ISSN 1641-3229.

Rozporządzenie Ministra Ochrony Środowiska, Zasobów Naturalnych i Leśnictwa z 6 kwietnia 1995 r. (Dz. U. Nr41 z dnia 18 kwietnia 1995 r., poz. 214).

Sokołowski A. W. 1970. Roślinność rezerwatu Cisowy Jar koło Olecka. Ochrona Przyrody, 35: 53-69.

Sokołowski A. W. (ed.) 2000. „Ekspertyza ochrony cisa oraz opracowanie założeń krajowej strategii ochrony tego gatunku”. Dokumentacja IBL, Warszawa.

Stanisz 2006. Przystępny kurs statystyki w oparciu z zastosowaniem Statistica PL na przykładach z medycyny. Tom 1. Statystyki podstawowe. Kraków, StatSoftPolska. ISBN978-83-88724-18-3.

Stypiński P., Krawczyk I., Giełwanowska I., Klarowski R. 1984. Rozmieszczenie i warunki występowania Taxus baccata L. na Warmii i Mazurach. Folia Forestalia Polonica, Ser. A, 24: 75-99.

Thomas P.A., Polwart A. 2003. Taxus baccata L. Biological Flora of the British Isles 229. Journal of Ecology, 91: 489-524.

Zaręba R. 1984. Możliwości reintrodukcji w lasach i utrzymania w rezerwatach cisa pospolitego - Taxus baccata $\mathrm{L}$ [Possibilities of reintroduction and preservation of common yew (Taxus baccata L.) in reservations]. Sylwan, 128, 11: 31-33.

Zarzycki K., Trzcińska-Tacik H., Różański W., Szeląg W., Wołek J., Korzeniak U. 2002. Ecological indicator values of vascular plants of Poland. Biodiversity of Poland 2. W. Szafer Institute of Botany, Kraków. p. 183. ISBN8385444955.

Translated by: Adam Kaliszewski 